\title{
Microscopic Evaluation of Concrete Samples from Manholes Exposed on Hydrogen Sulphide
}

\author{
Bartosz Bogusławski ${ }^{1 *}$, Sławomira Bering ${ }^{1}$, Jacek Mazur ${ }^{1}$, Krzysztof Tarnowski ${ }^{1}$, \\ Teresa Rucińska², Anna Głowacka ${ }^{1}$ \\ 1 EDP Department of Sanitary Engineering West Pomeranian University of Technology in Szczecin, al. Piastów 50, \\ 70-311 Szczecin, Poland \\ 2 EDP Department of Building Physics and Building Materials West Pomeranian University of Technology in \\ Szczecin, al. Piastów 50, 70-311 Szczecin, Poland \\ * Corresponding author e-mail: bboguslawski@zut.edu.pl
}

\begin{abstract}
The field test of the sewer system in a rural area was made. The results from two different pressure-gravity systems localized in two settlements were compared. The investigated sewer system operates in serial connection; the sewage from one settlement is pumped to the expansion well in the next one. In both systems, the high concentration of hydrogen sulfide, exceeding $200 \mathrm{ppm}$, and visible concrete wells corrosion effects were recorded. The samples of corroded concrete from the internal walls of the chosen wells were collected. The results of an electron microscope with the EDS attachment (Energy dispersive X-ray Spectroscopy) analysis showed a significant sulfur content in a concrete surface layer from $11.2 \%$ to $64.2 \%$ for the first system and from $7.53 \%$ to $42.9 \%$ for the second one. The exposure of concrete to high concentrations of hydrogen sulfide and relatively high content of sulfur on the surface of concrete might be a reason for hydrogen sulfide corrosion of concrete in the investigated systems.
\end{abstract}

Keywords: hydrogen sulphide corrosion, biocorrosion, pressure sewage system, hydrogen sulphide

\section{INTRODUCTION}

There are several mechanisms of corrosion in sewage systems. In the municipal systems, the concrete elements, i.e. pipelines and manholes, are especially exposed to the hydrogen sulfide corrosion. Retention time in the sewage pump station, given by German design code DIN EN 1671 is 4 hours. Detention time in the whole pressure sewage system (from source to wastewater treatment plant), given by Polish design code PN-EN 1671 (PN-EN 1671:2001. Zewnętrzne Systemy Kanalizacji Ciśnieniowej' 2001) should be less than 8 hours. As the field test shows (Worona 2012; Stachowiak, et al.; Głowacka and Bogusławski 2018), these values are exceeded and wastewater is detained in the system for even several dozen or more hours. Under such conditions, microorganisms use up dissolved oxygen and then conditions are changed into anaerobic. While there is no dissolved oxygen, bacteria use nitrates and subsequently sulfates (Dąbrowski 2013). Ayoub G. et al. (Ayoub et al. 2004) claim that the sulfate to sulfide reduction does not happen if the concentration of dissolved oxygen is greater than $0.5 \mathrm{mg} / \mathrm{dm}^{3}$, Hewdaye, et al. (2006) claim the minimum value as $0.1 \mathrm{mg} / \mathrm{dm}^{3}$, and Norsker, et al. (1995) - $1 \mathrm{mg} / \mathrm{dm}^{3}$. The sulfate-reducing bacteria living in the biofilm reduce sulfur from +6 degree to -2 . Under anaerobic conditions, divalent sulfur permeated from biofilm to wastewater and forms hydrogen sulphide.

Hydrogen sulfide gas might be a cause of corrosion of the upper elements of manholes, which does not have contact with wastewater. In the lower parts of manhole and pump stations, degradation may also be caused by mechanical corrosion or chemical reactions. On the upper parts, apart from gases, there also might be moisture deposition which favors the microorganism growth. 
Gases dissolve in moisture and become substrates for microorganisms. The sulfuric acid, which reacts with the components of concrete causing its degradation, constitutes a metabolism product of the sulfur-oxidizing bacteria. The literature says that Thiobacillus bacteria would colonize the surface of concrete only if the $\mathrm{pH}$ decreases to 9 (Roberts et al. 2002). The widely assumed theory is that lowering of $\mathrm{pH}$ (which initially is between 11-13) is caused by the carbonation process (Wells, et al. 2009; Bowker, et al. 1985). However, Yamanaka et al. (2002) suggest that the sulfur-oxidizing bacteria will grow in the layer even if the $\mathrm{pH}$ of the concrete itself ranges from 11-13. In their research, Tazawa EI. et al. (Tazawa, et al. 1994) observed that initially corrosion was caused by carbonic acid and organic acids which are produced by bacteria as well as fungi (Mori et al. 1992). Further $\mathrm{pH}$ lowering from 8 to 4 is also caused by bacteria and fungi (Mori et al. 1992). In many samples of corrosion, researchers found a microorganism whose influence on these processes is not well understood (US EPA 1991; Guangming et al. 2015).

The factors contributing to corrosion were outlined in many publications $[10,12,16,18]$ :

- BOD levels

- High sulfate and dissolved sulfide concentration

- High temperatures

- High $\mathrm{H}_{2} \mathrm{~S}$ concentration

- High turbulence and long detention times

- Low dissolved oxygen levels

- Low water velocity

- Low wastewater $\mathrm{pH}$

\section{MATERIALS AND METHODS}

The town covered by the research is located in the West Pomerania province. It is characterized by scattered housing. The tests in the system I were carried out in the period April-June 2018.
In the system II, first series of test were carried out in February 2019, the next one in July 2019. In both systems, the hydrogen sulfide and ammonia concentrations were measured in the manholes. The samples of corroded concrete were taken from the internal walls of wells to measure $\mathrm{pH}$ and for a microscope analysis. The hydrogen sulfide concentrations in wells were measured with a Draeger X-am 5000 multi-gas detector equipped with EC-Sensor XXS H2S with a measurement range up to $200.00 \mathrm{ppm}$. The measurements were performed using an external automatic gas suction pump from different depths of the well. In addition, the ammonia concentration (DraegerSensor XXS NH3, measuring range up to $300.00 \mathrm{ppm}$ ) was measured. The $\mathrm{pH}$ was measured in a water solution of the concrete samples using a Hach HQ40d pH meter with PHC 301 electrode. A Hitachi TM 3000 scanning electron microscope equipped with EDS unit was used in order to observe the elemental composition spectrum and determine the elemental composition of the analyzed concrete samples.

\section{Sewage system I}

This system is a gravity-pressure serial network. Wastewater flows in series of six settlements from S6 to S5 and so on to S1 and wastewater treatment plant. The tests were carried out in expansion wells, where the sewage from the previous settlement expands and further flows gravitationally to the pump station, which pumps it then to the next settlement. Manholes were marked corresponding to the number of towns in which sewage expands, i.e. EW3, EW2, and EW1. The settlements were labelled S1-S6. Figure 1 shows a scheme of the system I. Characteristics of sections from pump stations to studied expansion wells are shown in Table 1.

The estimated retention time in pipelines is from 6 to 27.5 hours. It means that sewage

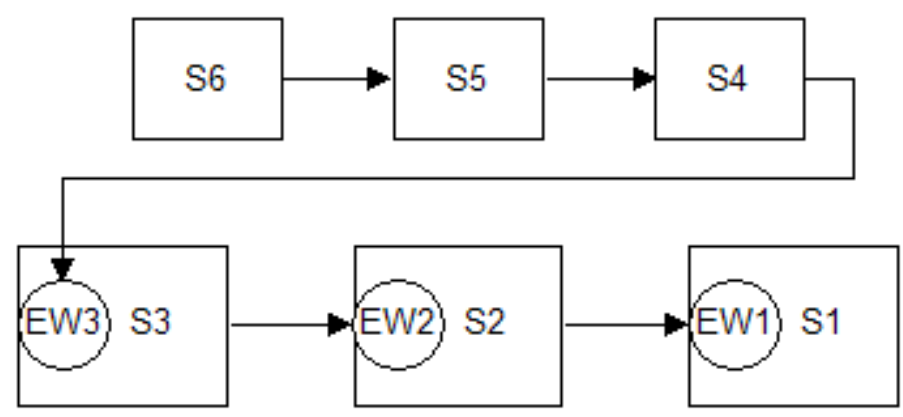

Fig. 1. Scheme of sewage system I. 
Table 1. Data about pipelines and estimated sewage detention time in network I

\begin{tabular}{|c|c|c|c|c|}
\hline \multirow{2}{*}{$\begin{array}{c}\text { Manhole } \\
\text { designation }\end{array}$} & Pressure pipe length & Diameter & Pipeline capacity & $\begin{array}{c}\text { Estimated detention time in } \\
\text { pipeline }\end{array}$ \\
\cline { 2 - 5 } & {$[\mathrm{m}]$} & {$[\mathrm{mm}]$} & {$\left[\mathrm{m}^{3}\right]$} & 18.5 \\
\hline I EW3 & 2715 & 125 & 25.9 & 6 \\
\hline I EW2 & 1671 & 125 & 15.9 & 27.5 \\
\hline I EW1 & 3445 & $125 / 160$ & 49.3 & \\
\hline
\end{tabular}

is detained for even more than a day (I EW1) in the closed pipe without an air supply, which is much more than design codes recommend (DIN EN 1671; PN-EN 1671:2001). Manholes are made of $\mathrm{C} 35 / 45$ concrete.

\section{Sewage system II}

The system includes 9 settlements, which are connected by the pressure-gravity network in the semi-parallel system. Figure 2 shows the scheme of the network. Towns 1 to 5 are marked figuratively as S1-5 because tests were not carried out at these settlements. The measurements were conducted in manholes marked as EW1, EW2 and pump stations - P2, P3.

The characteristics of the studied sections are shown in Table 2. The estimated retention time in pipelines is from 5.4 to 183.7 hours. In the worst case, sewage stays in the pipeline for more than a week (II P2 - II EW2). Such a long retention time results in dissolved oxygen depletion and, anaerobic conditions, anaerobic bacteria growth and consequently fermentation and hydrogen sulfide generation. In the case of the II EW2 expansion well, wastewater runs from two pressure pipelines. In one of them, the retention time is relatively short $(5.4 \mathrm{~h})$ but in the second, the retention time is much longer $(183.7 \mathrm{~h})$, for this reason, the manhole is endangered by hydrogen sulfide generated in the section with longer detention time. The II P2 and II P1 pump stations are made of polymer concrete. Other manholes and II $\mathrm{P} 3$ are made of concrete C35/45. Figure 3 shows the corroded II EW 2 manhole.

\section{RESULTS AND DISCUSSION}

\section{Concentration of gases}

Table 3 shows measurements of the concentration of hydrogen sulfide and ammonia in the air space of manholes in the network I.

The average concentration of hydrogen sulfide observed was from 67.6 to $82.8 \mathrm{ppm}$, but in every well, $0 \mathrm{ppm}$ of gas and also concentrations over the measurement range were observed. The observed ammonia concentrations ranged from 121.4 to $134.5 \mathrm{ppm}$. Similarly as in the case of hydrogen sulfide, very low values (5 to $8 \mathrm{ppm}$ ) and the values over the measurement range were observed. In the case of hydrogen sulfide, $7 \%$ of all measurements (I EW1) and 21\% (I EW3) were over $200 \mathrm{ppm}$. The ammonia concentrations over 300 ppm were from $13 \%$ (I EW1) to $21 \%$ (I EW3) of all measurements.

Table 4 shows average the results pertaining to the concentrations of hydrogen sulfide, ammonia and methane in air space of manholes in network II.

The average observed hydrogen sulfide concentrations ranged from 32.5 to over $200 \mathrm{ppm}$. The concentration of ammonia was from 121 to

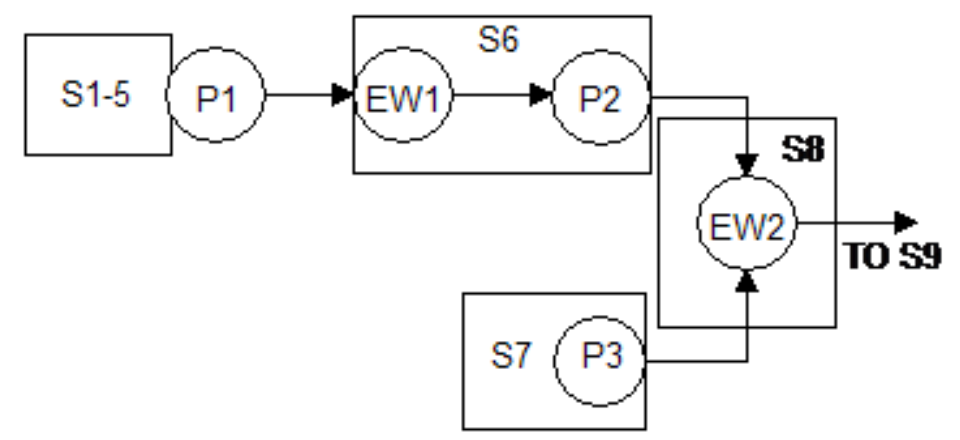

Fig. 2. Scheme of sewage system II. 
Table 2. Data about pipelines and estimated sewage detention time in network II

\begin{tabular}{|c|c|c|c|c|c|}
\hline $\begin{array}{c}\text { Manhole } \\
\text { designation }\end{array}$ & Section & $\begin{array}{l}\text { Diameter } \\
{[\mathrm{mm}]}\end{array}$ & $\begin{array}{l}\text { Length } \\
{[\mathrm{m}]}\end{array}$ & $\begin{array}{l}\text { Pipeline capacity } \\
{\left[\mathrm{m}^{3}\right]}\end{array}$ & $\begin{array}{c}\text { Estimated detention } \\
\text { time }[\mathrm{h}]\end{array}$ \\
\hline II P2 & \multirow{2}{*}{ P2-EW2 } & \multirow{2}{*}{176.2} & \multirow{2}{*}{2139} & \multirow{2}{*}{52.1} & \multirow{2}{*}{183.7} \\
\hline II EW2 & & & & & \\
\hline II P3 & \multirow{2}{*}{ P3-EW2 } & \multirow{2}{*}{110.2} & \multirow{2}{*}{1557} & \multirow{2}{*}{14.8} & \multirow{2}{*}{5.4} \\
\hline II EW2 & & & & & \\
\hline II P1 & \multirow{2}{*}{ P1-EW1 } & \multirow{2}{*}{141} & \multirow{2}{*}{3796} & \multirow{2}{*}{59.2} & \multirow{2}{*}{156.1} \\
\hline II EW1 & & & & & \\
\hline
\end{tabular}

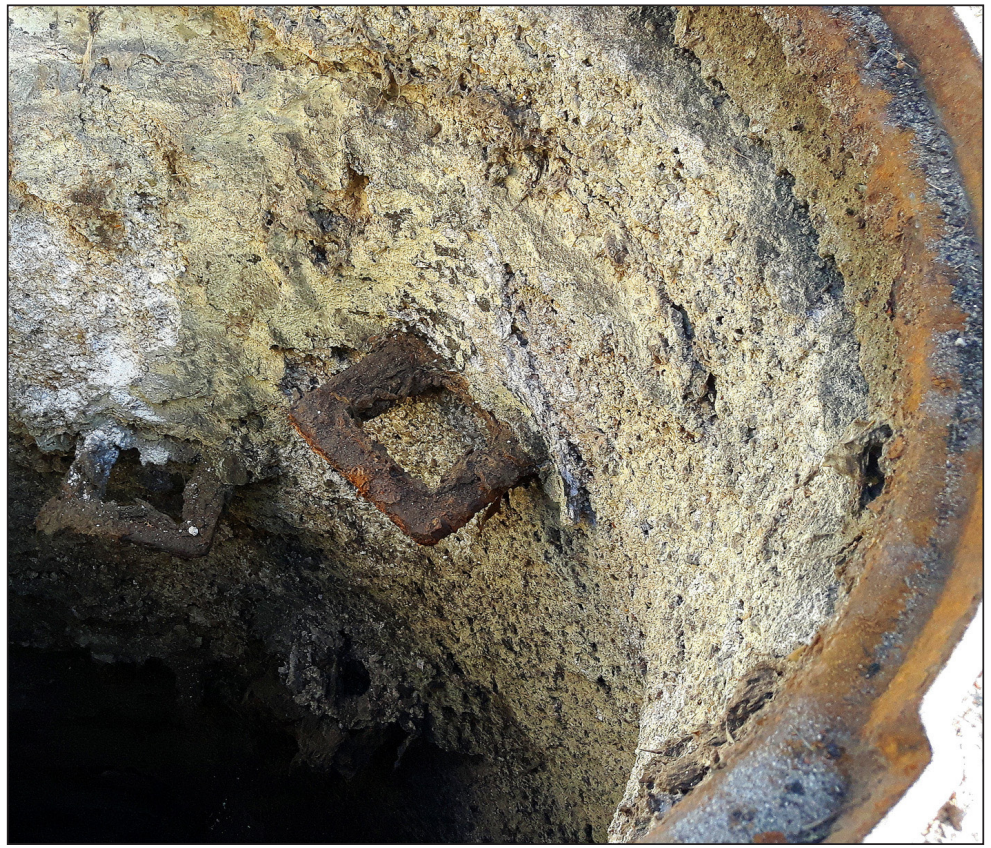

Fig. 3. Corroded manhole II EW2.

over $300 \mathrm{ppm}$. In the II P2 pump station and expansion well EW2 methane were observed. The measurements of gases concentration confirm the odor problem in the network and indicate hydrogen sulfide mechanism of corrosion.

\section{$\mathrm{PH}$ of concrete}

The $\mathrm{pH}$ of the water extract of concrete samples from I EW1 was 3.73. For comparison, a reference concrete was made in the laboratory. The $\mathrm{pH}$ of its sample was 10.76 (in literature, fresh concrete has pH 11-13 (O'Connell et al. 2010)). The conductivity of sample from I EW1 was $2.64 \mathrm{mS} / \mathrm{cm}$ and laboratory sample $0.61 \mathrm{mS} / \mathrm{cm}$.

Table 5 shows the $\mathrm{pH}$ and conductivity measurements in network II.

Low wastewater $\mathrm{pH}$ from 2.18 to 3.75 indicates the presence of acids in the water solution. The $\mathrm{pH}$ of laboratory concrete was 10.76 . In comparison to the laboratory value, a decreasing of $\mathrm{pH}$ by 7.01 up to 8.58 was observed. It means intensive processes of corrosion are going on in both systems.

Table 3. The average concentration of gases in the manholes in network I

\begin{tabular}{|c|c|c|c|c|c|c|c|c|c|c|}
\hline \multirow{2}{*}{$\begin{array}{c}\text { Manhole } \\
\text { designation }\end{array}$} & \multicolumn{4}{|c|}{$\mathrm{H}_{2} \mathrm{~S}[\mathrm{ppm}]$} & \multicolumn{5}{c|}{$\mathrm{NH}_{3}[\mathrm{ppm}]$} \\
\cline { 2 - 28 } & average & $\begin{array}{c}\text { standard } \\
\text { deviation }\end{array}$ & $\min$ & $\max$ & median & average & $\begin{array}{c}\text { standard } \\
\text { deviation }\end{array}$ & $\min$ & $\max$ & median \\
\hline I EW3 & 82.8 & 88.2 & 0 & $>200^{*}$ & 55.0 & 150.6 & 133.7 & 8 & $>300^{*}$ & 156.0 \\
\hline I EW2 & 67.6 & 77.9 & 0 & $>200^{*}$ & 31.0 & 134.1 & 134.5 & 6 & $>300^{*}$ & 40.0 \\
\hline I EW1 & 69.5 & 76.7 & 0 & $>200^{*}$ & 31.0 & 126.0 & 121.4 & 5 & $>300^{*}$ & 71.0 \\
\hline
\end{tabular}

* Above the measurement range, which was 200 ppm for hydrogen sulfide and 300 ppm for ammonia. 
Table 4. The average concentration of gases in the manholes in network II

\begin{tabular}{|c|c|c|c|}
\hline $\begin{array}{c}\text { Manhole } \\
\text { designation }\end{array}$ & $\mathrm{H}_{2} \mathrm{~S}$ & $\mathrm{NH}_{3}$ & $\mathrm{CH}_{4}$ \\
\cline { 2 - 4 } & {$[\mathrm{ppm}]$} & {$[\mathrm{ppm}]$} & {$[\%]$} \\
\hline II P2 & 170 & 290 & 0.05 \\
\hline II EW1 & 32.5 & 129.5 & 0 \\
\hline II P3** & 55 & 121 & 0 \\
\hline II EW2 & $>200^{*}$ & $>300^{*}$ & 0,8 \\
\hline
\end{tabular}

* Above the measurement range, which was $200 \mathrm{ppm}$ for hydrogen sulfide and 300 ppm for ammonia.

** Ferrox was dosed to II P3 pump station.

\section{Microscope analysis}

Figures 4, 5, 6 show the EDS microscopic analysis for a sample from network I, manhole

I EW3. Table 6 presents the results of the elemental composition analysis of the tested samples from system I. Table 7 presents the results of sample analysis in system II. This data was collected by Bogusławski B. et al. [2019] and here it is presented for comparison with system I. Table 8 presents the elemental composition of a new manhole sample.

\section{System I}

Table 6 presents the elemental composition analysis of the tested samples taken from the internal walls of wells in the system I.

The EDS analysis showed that in the system I, the main component in the tested concrete sample is oxygen, constituting from $34.4 \%$ to $49.63 \%$. A high share of sulfur from $29.25 \%$ to $35.43 \%$ was observed, which strongly suggests the occurrence of the a reaction between sulfuric acid and concrete components. Calcium (from $2.85 \%$ to $13.50 \%$ ) and silicon (from 6.3\% to $7.65 \%$ ) were also found in the samples. Carbon was identified only in a sample from well I EW1 - 14.35\%.

\section{System II}

Table 7 presents the elemental composition analysis of tested samples taken from the internal walls of wells in system II.

In system II, oxygen is also the main component (from $28.1 \%$ to $51.42 \%$ ). Sulfur has high share ranging from $7.53 \%$ to $42.9 \%$, which includes hydrogen sulfide corrosion mechanism. Calcium (from $0 \%$ to $23.58 \%$ ) and silicon $(0.4 \%$

Table 5. The $\mathrm{pH}$ measured in a water solution of concrete from the manholes in network II

\begin{tabular}{|c|c|c|c|}
\hline \multirow{2}{*}{ Manhole designation } & \multicolumn{2}{|c|}{$\mathrm{pH}$} & \multirow{2}{*}{ Average conductivity [mS/cm] } \\
\cline { 2 - 4 } & $\min$ & $\max$ & $3.55 \pm 1,35$ \\
\hline II EW1 & 2.18 & 3.52 & $2.65 \pm 0,25$ \\
\hline II P3 & 2.77 & 3.50 & $2.7 \pm 0,18$ \\
\hline II EW2 & 3.16 & 3.75 & 25 \\
\hline
\end{tabular}

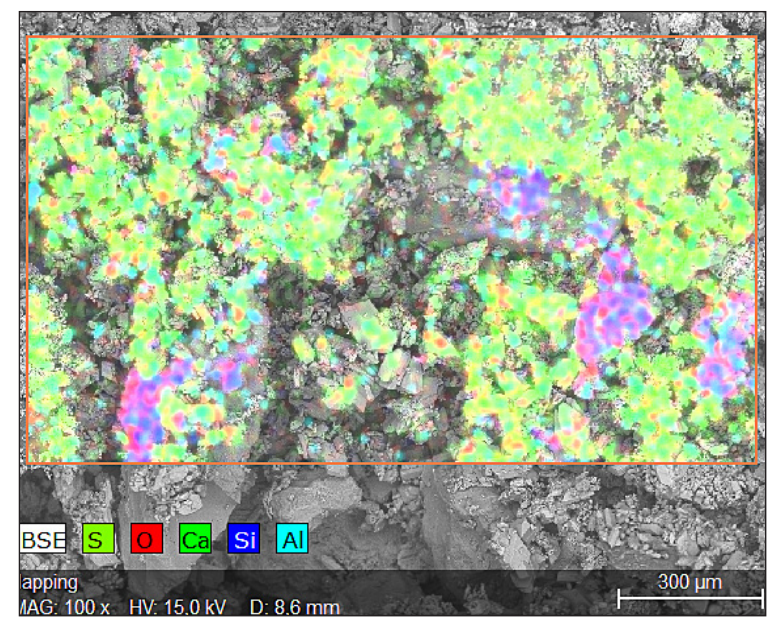

Fig. 4. Map of identified elements

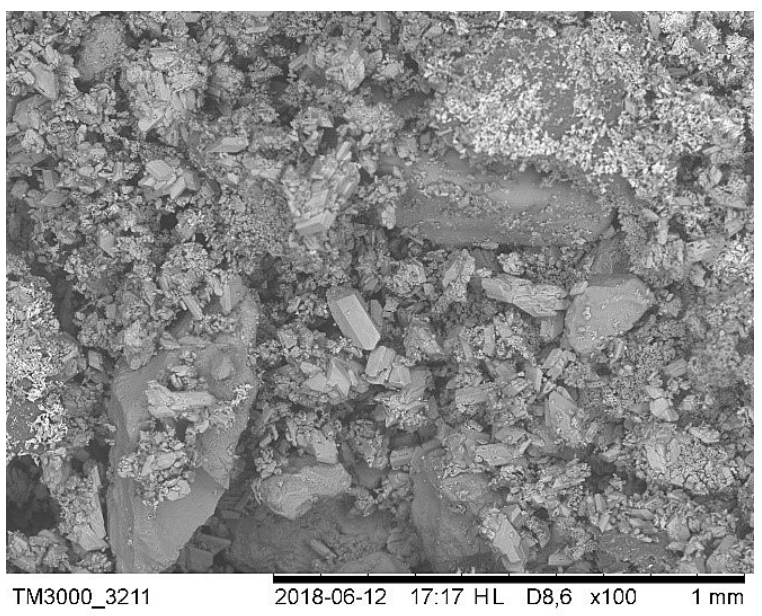

Fig. 5. SEM image of the external layer of the concrete, mag $\times 100$ 


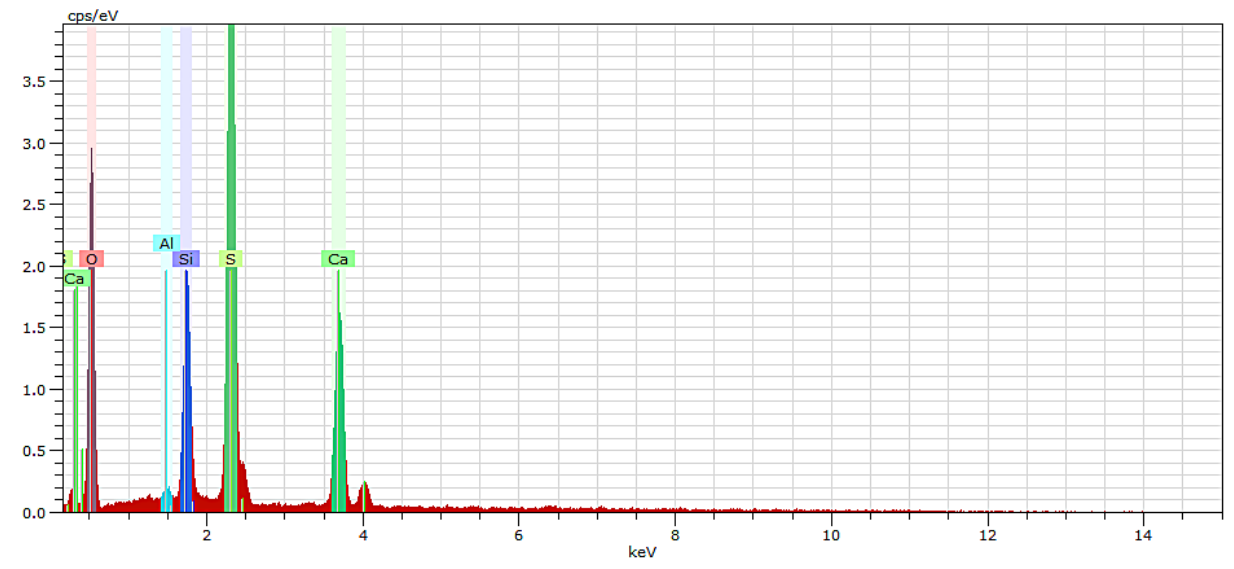

Fig. 6. Energy spectrum of elements identified on sample

Table 6. The average percentage participation of elements on the surface of samples [\%]

\begin{tabular}{|c|c|c|c|c|c|}
\hline \multirow{2}{*}{$\begin{array}{c}\text { Manhole } \\
\text { designation }\end{array}$} & \multicolumn{5}{|c|}{ Elements [\%] } \\
\cline { 2 - 6 } & $\mathrm{S}$ & $\mathrm{O}$ & $\mathrm{Ca}$ & $\mathrm{Si}$ & $\mathrm{C}$ \\
\hline I EW3 & $29,25 \pm 23,85$ & $49,63 \pm 14,17$ & $13,50 \pm 6,94$ & $7,65 \pm 7,55$ & - \\
\hline I EW2 & $35,0 \pm 21,86$ & $47,92 \pm 12,49$ & $10,8 \pm 5,05$ & $6,3 \pm 5,01$ & - \\
\hline I EW1 & $35,43 \pm 12,21$ & $34,4 \pm 6,78$ & $2,85 \pm 1,80$ & $6,40 \pm 6,34$ & $14,35 \pm 1,75$ \\
\hline
\end{tabular}

Table 7. Average percentage participation of elements on the surface of samples (Bogusławski, et al. 2019)

\begin{tabular}{|c|c|c|c|c|c|}
\hline \multirow{2}{*}{$\begin{array}{c}\text { Manhole } \\
\text { designation }\end{array}$} & \multicolumn{5}{|c|}{ Elements [\%] } \\
\cline { 2 - 6 } & $\mathrm{S}$ & $\mathrm{O}$ & $\mathrm{Ca}$ & $\mathrm{Si}$ & $\mathrm{C}$ \\
\hline II EW1 & $14,2 \pm 3,25$ & $50,47 \pm 1,25$ & $11,93 \pm 9,17$ & $2,83 \pm 2,31$ & $20,57 \pm 15,43$ \\
\hline II P2 & 42,9 & 28,1 & - & 0,4 & 28,7 \\
\hline II P3 & $7,53 \pm 4,17$ & $51,42 \pm 7,16$ & $10,17 \pm 6,98$ & $9,58 \pm 12,16$ & $20,43 \pm 18,91$ \\
\hline II EW2 & $20,25 \pm 1,18$ & $49,35 \pm 1,69$ & $23,58 \pm 3,27$ & $4,75 \pm 1,91$ & $2,10 \pm 2,40$ \\
\hline
\end{tabular}

Table 8. The average percentage participation of elements on the surface of the sample from a new manhole (Bogusławski, et al. 2019)

\begin{tabular}{|c|c|c|c|c|c|}
\hline Sample & \multicolumn{5}{|c|}{ Elements [\%] } \\
\hline & $\mathrm{S}$ & $\mathrm{O}$ & $\mathrm{Ca}$ & $\mathrm{Si}$ & $\mathrm{C}$ \\
\hline New manhole & 0 & $50.43 \pm 1.00$ & $19.07 \pm 7.93$ & $14.7 \pm 5.65$ & $10.27 \pm 1.67$ \\
\hline
\end{tabular}

to $9.58 \%$ ) were also observed. An important share of carbon was identified (2.1\% to $28.7 \%)$.

The sample taken from new manhole contains mostly oxygen $(50.43 \%)$ and calcium $(19.07 \%)$. Importantly, no sulfur was found, which indicates a high share of sulfur in the samples from network I and II due to the reactions between wastewater, gases, and components of concrete.

Single concentrations of sulfur were much more varied in network I (standard deviation $12.21-23.85 \%$ ) than in network II (standard deviation $1.18-4.17 \%$ ), but the average sulfur share from many photos of the same sample was much more varied in system II than in system I.

\section{CONCLUSIONS}

The studied systems have similar characteristic; hence, no significant differences in the results of gases concentrations, $\mathrm{pH}$ and elemental composition were observed. The retention times in pipelines are more significant in network II but in both are much higher than recommended in the literature. The oxygen from sewage is used up after several hours, consequently, in the studied systems, most of the time sewage is under anaerobic conditions. During expansion in the expansion well, hydrogen sulphide is released and causes odor and corrosion problems. 
High concentrations of hydrogen sulphide were observed, often exceeding $200 \mathrm{ppm}$. Low pH of water solution of concrete taken from internal walls of manholes (compared to the control sample) from 2.18 to 3.75 indicates the presence of acids, which reacts with concrete components. The EDS analysis showed a high share of sulfur in the surface layer of concrete. In system I, the share was between $29.25-35.43 \%$, wherein the highest observed was even $64.2 \%$. In system II, the share was from $7.53 \%$ to $42.9 \%$. It indicates the occurrence of reactions between sulfuric acid and compositions of concrete.

\section{REFERENCES}

1. Ayoub, George, N Azar, M El Fadel, and B Hamad. 2004. Assessment of hydrogen sulphide corrosion of cementitious sewer pipes: A case study. Urban Water Journal, no. 1: 39-53.

2. Bertran de Lis, F, E Saracevic, and N Matsche. 2007. Control of sulphide problems in pressure sewers. Novatech, 965-72.

3. Bogusławski, B., A. Głowacka, and T. Rucińska. 2019. Microscopic evaluation of manholes in selected sewerage pressure system. Civil and Environmental Engineering, no. 29: 31-40.

4. Bowker, R.P.G., J.M. Smith, and N.A. Webster. 1985. Odor and corrosion control i sanitary sewerage systems and treatment plants. Design Manual. U.S. Environmental Protection Agency.

5. Dąbrowski, W. 2013. Nieporozumienia dotyczące korozji siarczanowej kanałów. Instal, no. 1: 33-36.

6. DIN EN 1671 Druckentwässerungssysteme Außerhalb von Gebäuden.

7. Głowacka, Anna, and Bartosz Bogusławski. 2018. Badanie skuteczności napowietrzania ścieków w wybranych systemach kanalizacji ciśnieniowej przy zastosowaniu aplikatora powietrza typu Atol-Oxy. Instal, no. 10 (399): 33-37.

8. Guangming, Jiang, Sun Jing, Sharma Keshab, and Yuan Zhingo. 2015. Corrosion and odor management in sewer systems. Current Opinion in Biotechnology, no. 33: 192-97.
9. Hewayde, Esam, Moncef Nehdi, Erez Allouche, and G Nakhla. 2006. Effect of geopolymer cement on microstructure, compressive strength and sulphuric acid resistance of concrete. Magazine of Concrete Research, 58 (5): 321-31.

10. Hydrogen Sulfide Corrosion in Wastewater Collection and Treatment Systems. 1991. Technical Report. Washington: U.S. Environmental Protection Agency, Office of Water (WH-595).

11. Mori, T, T Nonaka, K Tazaki, M Koga, Y Hikosaka, and S Noda. 1992. Interactions of nutrients, moisture and $\mathrm{PH}$ on microbial corrosion of concrete sewer pipes. Water Research 26 (1): 29-37.

12. Norsker, Niels, Per Nielsen, and Thorkild HvitvedJacobsen. 1995. Influence of oxygen on biofilm growth and potential sulfate reduction in gravity sewer biofilm. Water Science and Technology 31 (7): 159-67.

13. O'Connell, M, C McNally, and M.G. Richardson. 2010. Biochemical attack on concrete in wastewater applications: A state of the art review. Cement and Conrete Composites, no. 32: 479-85.

14. PN-EN 1671:2001. Zewnętrzne systemy kanalizacji ciśnieniowej. 2001.

15. Roberts, DJ, D Nica, G Zuo, and JL Davis. 2002. Quantifying microbially induced deterioration of concrete: Initial studies. International Biodeterioration and Biodegradation 49 (4): 227-34.

16. Stachowiak, M., M. Troszczyńska, and Z.Dymaczewski. 2017. Przeciwdziałanie uciążliwości odorowej w systemach kanalizacji grawitacyjnotłocznej. Technologia Wody, no. 6: 38-45.

17. Tazawa, EI, T Morianga, and K Kawai. 1994. Deterioration of concrete derived from metabolites of microorganisms. 1087-97. Nice, France.

18. Wells, Tony, Robert Melchers, and Phil Bond. 2009. Factors Involved in the Long Term Corrosion of Concrete Sewers.

19. Worona, J. 2012. Śmierdzi w kanale. zagniwanie ścieków w kanalizacji tłocznej. Ochrona Środowiska, no. 5.

20. Yamanaka, T, I Aso, S Togashi, M Tanigawa, K Shoji, and T Watanabe. 2002. Corrosion by bacteria of in sewerage systems and inhibitory effects of formates on their growth. Water Research 36 (10): 2632-42. 